\title{
LAINEID LÖÖVA „VEA” JUURED: PRESIDENDIKANPAANIA JA SELLE TAUST
}

1. juunil k.a tõmmati Tõnismäel üles Edgar Savisaart presidendiks valima õhutav loosung, millelt võis muuhulgas lugeda Presidendikandidaadi kanpaania. Agarad ajakirjanikud ja netikommentaatorid kuulutasid kanpaania jalamaid kirjaveaks, mis see olemuslikult täiesti ilmselt siiski ei ole. „Viga” johtub vene rahvakeele sügavatest hoovustest. Sõnasisene $m b, m p$ on vene häälikusüsteemile tegelikult võõras konsonantühend, esinedes üksnes laenudes ja varieerub sageli $n b$-, $n p$-ga. Vanemates (suulistes) laenudes on ootuspärase, laenualusele vastava $m b, m p$ kõrval registreeritud sageli rahvakeelde ilmselt paremini sobiv variant, nt имбй́ kõrval ka инбиір 'ingver' (< pl imbir) < uus- üsks Imber (Vasmer II: 129), ^ámna kõrval ла́нna 'lamp', ^амnáda kõrval ланпа́da 'lampaad, väike õlilamp pühakuju või -pildi ees' (Vasmer II: 455), ،aмnác kõrval ıанnác 'lampass, (lai) värviline pael (vormi)pükste küljeõmblusel' (< sks Lampas) $<$ pr lampasse (Dahl II: 236; Vasmer II: 455), шо́мпол jt ning щонпал'püssivarras, varras püssiraua õone puhastamiseks ja õlitamiseks' < pl sztępel < sks Stempel (Vasmer IV: 466) jt. Struktuurivõõrast konsonantühendit on võidud suupäras-

\section{Kirjandus}

Blokland, Rogier 2009. The Russian Loanwords in Literary Estonian. (Veröffentlichungen der Societas Uralo-Altaica 78.) Wiesbaden: Harrassowitz Verlag.

Dahl I-IV = Владимір Даль, Толковый словарь живаго великорускаго языка Владиміра Даля I-IV. С.-ПетербургьМосква: Издание книгопродавца-типографа М. О. Вольфа, 1880-1882. tada ka nii, et emb-kumb kaashäälik on kadunud, nt домра' 'dombra' < turgi, vrd tatari dumbra (Vasmer I: 528). Venekeelsest sotsiaalmeediast võib hõlpsasti leida kirjakeele normist hälbivaid rahvakeelseid $n b$-, $n p$-lisi sõnakujusid. Mõned näited: Посоветуйте кухонный канбайн, чтобы из мяса делать фари 'Soovitage köögikombaini, et lihast teha hakkliha', канбайнер пашет, тут сталевар --- плавит pydy 'kombainer künnab põldu, --- siin terasesulataja sulatab maaki', бутылккy шанпаня 'pudel šampanjat', куда конпас повернул, туда и приедешь 'kuhu kompass keeras, sinna sõidadki'. Jne.

Eesti keele vene laenude hulgas kirjeldatud tüüpi näiteid ei ole registreeritud, mida kinnitavad vene-eesti laenusuhete representatiivsed käsitlused, nagu Must 2000 ja Blokland 2009. kanpaania oleks seega esimene sellelaadne juhtum.

Niisiis mitte kirjaviga, vaid peegeldus kehtivast standardist hälbivast keeleuususest, mida kannavad meie kõrval elavad, mitmest Venemaa nurgast Eestisse asunud venekeelsed inimesed, vahendades seda ka eesti keelekonteksti.

LEMBIT VABA

Must, Mari 2000. Vene laensõnad eesti murretes. Toim Lembit Vaba. Tallinn: Eesti Keele Sihtasutus.

V a s m e r I-IV = Макс Фасмер, Этимологический словарь русского языка I-IV. Перевод с немецкого и дополнения академика РАН О. Н. Трубачева. Москва: Астрель Аст, 2004. 